\title{
Neo-Orientalism and the Search for Identity
}

\author{
REEMA ABU HASSAN \\ American University of Sharjah
}

\begin{abstract}
The recent emergence of neo-orientalist architecture has become prevalent within the non-western world. This raises ethical questions about the way recent architectural and urban developments have been attempting to keep up with globalization and western technological advances while also holding onto their national identities and collective memories. This struggle of mediating local cultures and modernity as a reflection of society within the built environment has been a concern since the start of post-colonialism and orientalism. This paper will look at the way humanism kick started this issue and how the resulting orientalism and colonialism have influenced the built environment through a critical look at modernity, national identity, manipulated and constructed memories and the rise of neo-oriental architectural production. We will also look at the non-western world's constant need to define and reference historical and cultural roots in the production of today's architecture and the role that it's colonized past plays. Throughout the paper we will look into examples from the built environment and into how the architect attempted to find a middle ground between modernity and vernacular architecture while attempting to allow local values and society to influence the work.
\end{abstract}

\section{HUMANISM AND THE ERADICATION OF ALTERITY}

Humanism is regarded as a thought paradigm that is typically held responsible for the birth of modernity. In humanism, man becomes the center of the universe as a rational 'being' and this centralizing and dignifying of man created man as an active entity, as opposed to a passive receiver. Descartes' 'Cogito ergo sum,' which is translated as "I think, therefore I am" is one of the fundamental foundations of Western thought and it supports humanism's centrality of man (Descartes, 1637). Through seeing man as a rational thinker, man gained dignity and this gave certain people the power to say that some are more human than others. Once humans became subjects, they began to only objectify what they understood through their use of reason and this led to the exclusion of the 'other.' This exclusion occurred because what was framed as real became what one controls and uses for one's benefit. These developments in Western thought led to the eradication of alterity and to the emergence of homogeneity, which contributed to the history of violence within the West. This meant that everyone must conform to homogenous ideals and standards set forth by western societies, and as a result these movements ultimately caused the emergence of the discussions of colonialism, orientalism and racism.

\section{COLONIZATION AND ORIENTALISM}

The West's colonization of the non-western world is a reflection of the way in which they regarded the colonized as 'other' to themselves. Their attempts to 'civilize' the colonized was done in order to make them similar to themselves and to see a reflection of themselves in the 'other.' This is where Edward Said, who is the founder of Postcolonial studies, comes into the picture. He argues that one of the orient's most recurring images is that of the 'other' and he defines Orientalism as "a way of coming to terms with the Orient that is based on the Orient's special place in European Western Experience (Said, 1978)." He argues that for the west, anyone who is not the same is seen as an outsider who is inferior, uncivilized and primitive. He builds onto Emmanuel Levinas's, who was a French ethical philosopher, ideas of decentralization and of the breaking down of humanism (Levinas, 1960) and argues that orientalism came to rise through colonialism (Said, 1978). This is what led to the conflict and the struggles between the west and the non-west and this brings us to the impact that humanism, orientalism and colonization had, and still have, on the built environment of the non-West.

\section{COLONIZATION, NATIONAL IDENTITY AND THE BUILT ENVIRONMENT}

Colonialism brought Modern architecture to the nonwestern world, and it began to replace the local vernacular that was there prior to its arrival. The newly colonized lands became laboratories for European architects and urban planners (Osten, 2010). The local vernacular built environment, which reflected the cultural traits of the people and their society, was replaced by modern architecture because it was seen as backwards and uncivilized by the West because of the fact that it did not fit into the norms of the colonizers (Djiar, 2010). This spread of modernism, as a result of colonization, throughout diverse socio-political contexts erased many national identities and traditional vernacular architecture in the third world, because of the difficulty of balancing modernism with existing context and culture. Traditions were lost and when the colonizers left, the locals felt like their traditions needed to be brought back. Could this be the reason why one of the main traits of post-colonialism is the need to revive and hold on to previously threatened national identities? After all, postcolonialism led to a situation where creating a nation that links to a certain past became a most vital and yet complex aim for post-colonial countries (Mitchell, 1998). 

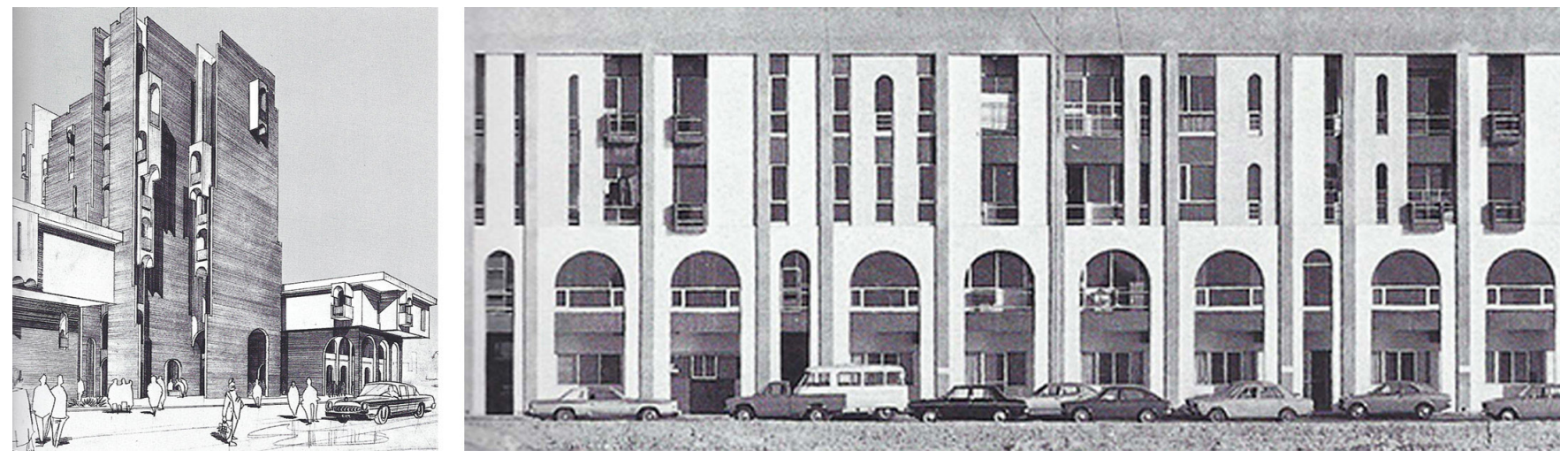

Figure 1: Rifat Chadirji's work from his book Concepts and Influences: Towards a Regionalized International Architecture, 1986.

The creation of a national identity, particularly in postcolonial areas, requires the search for memory and for its representation, in this case through architecture, and this touches very significantly upon questions of identity, nationalism, power and authority. It often requires forgetting and erasing certain parts of the past and questioning not only what is remembered but how and in what form it is remembered. As a result, manipulation and invention play a role in such matters as tradition and collective historical experience (Hobsbawm, 1983). It always involves narratives that are constantly sought after and because of the rapid social transformation that was undergone by the colonized non-western world, it seems to be stuck in an era of a search for roots while simultaneously attempting to employ the west's modern technology. This occurs as an extension of the fact that the indigenous people under colonial rule felt the need to hold on to tradition as a way to remain loyal to their sense of nationality as a rejection of colonialism (Djiar, 2010). Once colonization ended and the people were freed they felt a strong need to continue holding on to their national identity and this left them in search of a post-colonial state and a struggle arose between returning to pre-colonial ways and adopting the modern ways set into motion by the colonizers. These issues became a concern in the post-colonial built environment as well, but the question that arises is why is it that post-colonized countries did not go back to their traditional building and vernacular developments once they became independent and why is this not what is done today as opposed to the neo-orientalist architectural production? Could it be that the very culture that had created the country's vernacular architecture had been so altered after colonization, that they needed, and still need, a new architecture to reinforce the change as well as the independence? Older traditions were unadaptable and became rapidly unviable and thus new traditions simply resulted from the inability to use or adapt to older ones. On the other hand, why wasn't purely modern architecture the solution for post-colonial cities? Could it be that the pure modern architecture, that did not relate to the past and did not grow from cultural roots, did not get adopted because it would mean erasing the history of colonization, which had become an important part of the country's history and of the people's collective memory (Curtis, 1996)? This created a need to find a new post-colonial architecture that somehow finds a middle ground between the two. This confusion in finding an alternative modern architecture that works for the region led to the non-western world's constant need to attempt to revive old memories and to reinforce identities of the place through attaching parts of the vernacular to the modern, which planted a seed of neo-orientalist architecture. Despite all of this there emerged some work by pioneering post-colonial architects that found a balance between modernity, pre-colonial and post-colonial national identities and is now being threatened and erased by the production of the neo-orientalist architecture. An example of an architecture that finds a middle ground between the conflicting motives in architectural design in the post-colonial cities is the work of Rifaat Chadirji. In his book titled Towards a Regionalized International Architecture he discusses his thinking behind his designs and presents to the reader an international architecture in its concepts and technology, but also embodies a regional character that is the result of the interaction of social and technological needs. He also mediates between the western and non-western approaches to the built environment by stating that: his designs "would be based on my awareness and acceptance of modern western aesthetic values and technology as part of an international culture and a global economic system. Secondly, and apparently incompatibly, I was determined to refer consciously to regional traditional values, to allow them to influence me, to produce designs that were congenial to the values of these ancient and traditional cultures and to experiment, with the aim of generating a modern regional architecture (Chadirji, 1986) )(Figure 1)."

With the rise of globalization and western technology neoorientalist architectural production gained greater speed and has become wide spread in recent years in the non-western world. It led to an even greater struggle of integrating modern technologies with 'traditional' architecture. The attempt to position a city globally became a major concern in the rapidly 

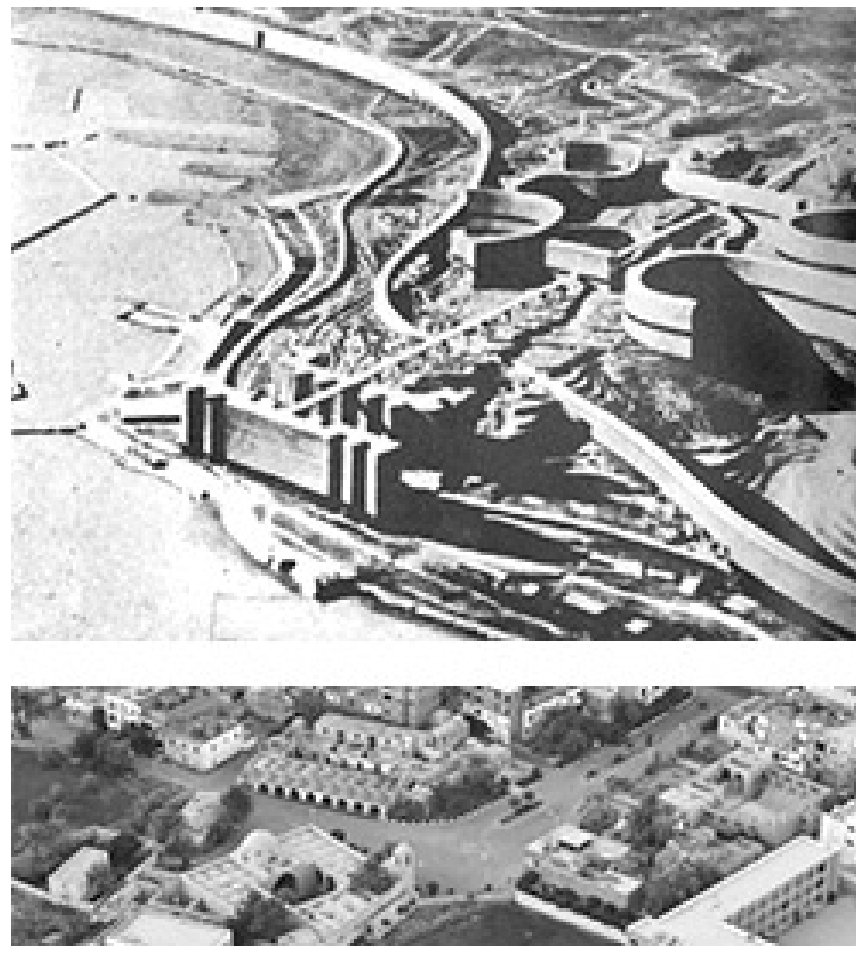

Figure 2: Corbusier's Algiers Plan Obus and Hassan Fathy's Gourna Village.

globalizing world because of the global competition which is creating a globally compressed world. Thus, societies find it hard to identify with an individual or a collective identity and it "becomes difficult to comprehend globalization without recognizing the historical specificity of traditional cultures, their colonization, and their later emergence as nation-states (AlSayyad, 2010)."

Non-western nations now struggle with the desire of belonging to a larger and globalized modern civilization while simultaneously pursuing of an authenticity of nationalism. The solution which is currently utilized is the superficial and neo-orientalist approach of attaching a constructed identity or memory to architecture (Khan, 2012). An example of this orientalist architecture was seen in the orientalist architectural production within numerous places such as the Gurna Village, Hassan Fathy's project of inventing 'Modern Vernacular' architecture, which seems to contradict itself. He claimed to have wanted to revive the peasant's faith in his own culture, but then invents that very culture. In this context of Egypt one witnesses the need to turn historical or 'cultural' sites into a preserved site protected for tourists, which are usually Westerners (Fathy, 1969). Fathi's village's inhabitants were segregated from the tourists by the building of a bridge above of the village for tourists to view the village, which is similar to Corbusier's street above the Casbah in Algiers in his plan Obus, which symbolizes dominance, segregation and surveillance and that was built during colonial rule in Algiers (Celik, 1992)(Figure 2). Le Corbusier's plan almost ignored functioning housing structures or inhabitants who might have had their own logics of settlement. Corbusier looked at the Casbah in poetic terms and ignored oppression and suffering and did not address the suffering of the people of Algiers. Framing the Casbah made it seem like a museum piece and made it a place for Europeans to go see and observe the 'others.' This preservation of historical and vernacular architecture has become a way of promoting tourism which is increasingly important within today's globalized world. The double role of learning from the vernacular, on the one hand, and of abstracting it from the everyday context and translating it into aesthetic models on the other is grounded in colonial perceptions and narratives. "This role of acknowledging, translating and ignoring was bound to the idea of tabula rasa, an uninhabited and or "uncivilized" space, a characteristic feature of the territorial imaginations, practices, and representational policies of colonial modernism (Osten, 2011)." Doesn't this lead to the reinforcement of the Western perception of an Islamic, timeless and Oriental city characteristic of the colonial times? So does this development of tourism within the non-western world exist as an act of present day colonization that attempts to establish modern and global cities? The Orient seemed to exist purely for Western experience, which tended to emphasize the notion of the orient as 'the other' (Said, 1978). Non-western culture tends to be depicted and portrayed as an ideal and non-changing one in order to attract visitors; which reinforces the western thoughts of 'the orient'. The West viewed Islamic cultures as timeless and stagnant. The way in which architecture over the past few decades seems to be creating an image of neo-orientalist architecture that is produced to embody and reference these so called 'stagnant cultures' and this reinforces the orientalist view of the non-western world. Modern day examples of this creation of an experience of the vernacular include projects such as the Louvre in Abu Dhabi that has been designed and laid out to reference an Arab medina and to offer visitors and tourists an experience similar to that of walking through a vernacular Arab medina (figure 3). So why is there the need to reinforce the idea that the 'Arab medina' is a part of the country's national identity and to recreate that vernacular experience? Is this tendency to design and build architecture with a direct literal reference to a specific past a way to promote and depict a certain story or identity as a promoter of tourism for westerners to experience the non- west, and could this be seen as a continued act of colonization to assert the west's preconceived image of the orient?

Architecture is the expression of what is going on in a society and the understanding of the relationship between culture and architecture plays an important role in the production of the built environment (Djiar, 2010). A close look at the colonial and post-colonial architecture is necessary to the understanding of today's rise of neo-orientalist architecture because it is the most communicative form of a place's culture 


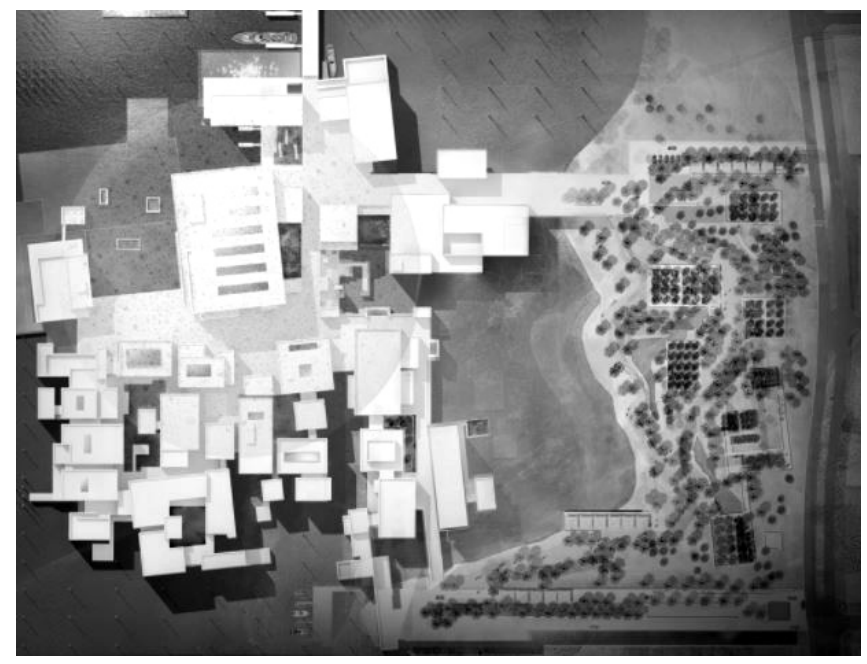

Figure 3: Plan of the Louvre Museum in Abu Dhabi, United Arab Emirates.
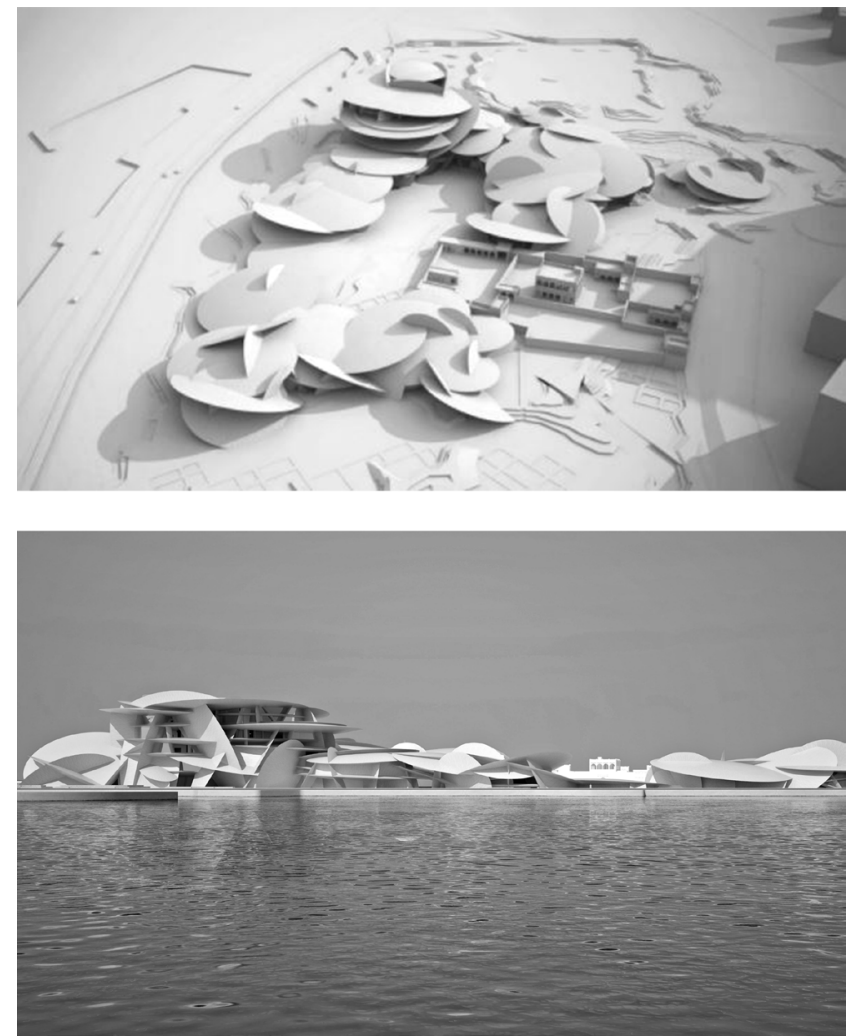

Figure 4: Qatar National Museum

and society. So is this modern need to position oneself on the global stage and to simultaneously hold onto a historically rooted culture through the creation and weaving of narratives and artificial references an ethical way for the non-western world to develop its built environment? Is the holding on to constructed and flat identities the way to preserve national identities? Does the abandonment of these identities eradicate the alterity and otherness of today's world and create a homogenized one? Levinas argues that we need to accept the otherness of the other, are artificial references the only way to do so, even if it has been manipulated, constructed and used as a vehicle for progress and modernization? Could we accept neo-orientalism as a different modernity for the nonwestern world as a result of globalization and technological advances and could it be seen as ethical even if it threatens to erase the work of pioneering post-colonial architects?

I argue for a rejection of attaching a story of the past in an attempt to revive and retain a collective memory. Why can't we just preserve the old buildings that are an authentic reflection of that past and of that past's society instead of attempting to depict, reinvent and recreate it in today's built environment? An example of a project that preserves the past while attempting to test and a new architecture for the region is the national museum of Qatar (figure 4). Regardless of the design and construction, what is to be taken away from the approach is that it preserves the old buildings on the site that are old vernacular buildings. It then does not take a constructed narrative to justify the design of the museum or attempt to attach traditional vernacular architectural elements to reference the past. It also does not attempt to recreate a flat experience such as that of walking through an Arab Medina that was previously mentioned in the Louvre in Abu Dhabi. The Qatar National Museum does not attempt to preserve and create a flat image of the traditional architecture of the area. We should not make flat historical references in an effort to hold onto our past national identity, we as architects should experiment with new approaches while allowing the regional traditional values of our cultures to influence us and to create a modern regional architecture that is devoid of flat artificial references to constructed national identities. As the architect Robert Venturi says "As architects of our time we are here not to suppress our culture, but to express it; perhaps less to solve our dilemmas than to reflect them" (Chadirji, 1984).

\section{BIBLIOGRAPHY}

1 Avermaete, T. (2010). Colonial Modern: Aesthetics of the Past Rebellions for the Future. London: Black Dog Publishing.

2 Chadirji, R. (1986). Concepts and Influences: Towards a Regionalized International Architecture. London: KPI, Limited.

3 Celik, Z. (1992). Le Corbusier, Orientalism, Colonialism. Massachusetts: The MIT Press

4 Curtis, W.R. (1996). Modern Architecture since 1900. London: Phaidon Press

5 Fathy, H. (1969). Architecture for the Poor: An Experiment in Rural Egypt. Chicago: University of Chicago Press

6 Hobsbawm, E. (1983). The Invention of Tradition. Cambridge: Cambridge University Press

7 Khan, H. (2012). "Editorial: towards a new paradigm for the Architecture and Arts of Islam." International Journal of Architecture.

8 Levinas, E. (2003). Humanism of the Other. Chicago: University of Illinois Press

9 Mitchell, T. (1998). Making the Nation: The Politics of Heritage in Egypt.

10 Said, E. W. (1978). Orientalism. New York: Pantheon Books. 